\title{
Developing Indicators to Implementing Green Material Management in Construction Industry: A Literature Review
}

\author{
Nur Farida ${ }^{1}$, Naniek $U$. Handayani ${ }^{1, *}$, Mochamad A. Wibowo ${ }^{2}$ \\ ${ }^{1}$ Department of Industrial Engineering, Faculty of Engineering, Diponegoro University, Semarang - Indonesia \\ ${ }^{2}$ Department of Civil Engineering, Faculty of Engineering, Diponegoro University, Semarang - Indonesia
}

\begin{abstract}
Material waste is one of waste that has been identified as a significant problem of the construction industry and also has a negative impact on the environment. Therefore, it is necessary to find the way to increase the efficiency of material used and minimize environmental impact. Green material management is one of the concepts that are a part of green supply chain management. This concept is commonly used in manufacture industry. The purpose of this study is to adopt the concept of green material management in manufacture industry to apply for the construction industry. A literature review was conducted to learn from previous research about the implementation of green material management in manufacture and construction industry. Some previous research has been figured out the framework of green material management in the construction industry, but the result are still limited to identify the concepts, dimensions, and elements. Indicators are needed so the concept can be applied appropriately and clearly. The result of this study is a framework of green material management concept in the construction industry that consists of five dimensions, 16 elements, and 20 indicators.
\end{abstract}

Keywords: construction industry; green material management; indicators.

\section{Introduction}

Construction industry commonly known as industry with high level of waste. Construction industry waste focused on amount of material waste on site and also several activities like over production, waiting time, process handling of material, inventory, and worker movement. The main waste categories along construction process can be described as: rework/repair, defect, material waste, delay, waiting time, unsuitable material allocation, and unnecessary material handling [1].

Material waste is one of waste that have negative impact on environment. Some researches in some country show that construction and demolition waste $(C \& D$ waste) have a great contribution to all solid waste in that country (about $13-30 \%$ in each country) [2]. Furthermore, negative effect on environment also caused by consuming a lot of material, large amount of energy needs, and pollution generated along construction supply chain.

In other reference, according to [3], material waste has been identify as a major problem in the construction industry. It is defined as the difference between the value of material delivered and accepted on the site and those properly used as specifie

$\mathrm{d}$ and as accurately measured in the work. There is a big attention on both implications of the efficiency and the environmental impact on construction projects [4].

From that explanation before, recently, the great issues that becomes a main concern in construction management is amount of waste generated and inefficiency that happen in it's stages. Moreover, the construction industry pays inadequate attention to the protection for the environment. The concept of sustainable construction has emerged as one of alternative solution to face that problem [5].

To answer material problem of construction, it is necessary to find the way to increase efficiency of material used and minimize environment impact. Green material management is one of the concept that are a part of Green Supply Chain Management. According to [6], one of the most reasonable actions in GSCM in manufacture industry is to replace a potentially hazardous material or process by the other that more environmental friendly. The concept of green material management in manufacture industry supports to achieve sustainable construction, especially to answer the problem that happens to material aspect. This study aims to adopt green material management concepts of manufacturing industry to applied in construction industry.

\section{Literature Review}

\subsection{Supply Chain in Construction}

Construction industry is unique and has many special characteristics. According to [7], construction industry is unique because every project just deliver one kind of product, so the definition of construction supply chain is different with manufacture supply chain. Muya in [8]

* Corresponding author: naniekh@ft.undip.ac.id 
mentions that there are three types of construction supply chain:

1. The primary supply chain - which delivers the materials that unit into the final construction product.

2. The support chain - which provides the facility such as equipment, expertise, and materials.

3. The human resource supply chain - which manages the supply of labour.

Construction supply chain must have flexibility to adjust the need of every customer that have unique requirements. That requirements cause the construction sector has very different types, sizes, and level of difficulties. The other impact is the high degree of subcontracting within the industry [8].

\subsection{Green Supply Chain Management in Construction}

Green supply chain management (GSCM) can be defined as integrating environmental spirit into supply chain management, including product design, material resource and selection, manufacturing processes, delivery of the final product to the customer, and end of life management of the product after its useful life [9]. GSCM purposes to preserve natural resources, minimize generation waste through reuse, recycle, and remanufacture the materials, as good as reduce pollution [10]. According to Sarkis in [10], there are three main factors that becomes concern when converting supply chain management into green supply chain management. They are product life cycle, operational life cycle, and waste minimization.

The concept of GSCM in manufacture has been studied and to be applied in construction industry in many researches. That researches vary in scope, purpose, and case study. Balasubramanian in [11] developed GSCM assessment framework that consists of nine constructs. Elbarkouky in [10] presented a framework for classifying essential GSCM requirements for the construction industry, and also identify drivers and barriers of applying GSCM in developing countries. Wibowo in [12] developed GSCM framework in construction industry that consists of five concepts, 22 dimensions, and 82 elements. This result is found by Delphi study. Five concepts that are developed are green idea, green product design, green material management, green construction, and green operation and maintenance.

Green idea is discussing about project life cycle between owner and consultant so that owner can realize environment impact of construction waste. Green product design talk about how to design building without damaging the environment. Green material management is a method to eliminate hazardous material or activities then replace with less harmful ones. Green construction processes consists of three phases: resource utilization decrement, waste decrement, and emission decrement. Green operations and maintenance is a plan that combining cleaning, work practices, training and surveillance of materials in a project in environmentconcerning [12].

\subsection{Sustainable Material Management in Construction}

Environmental Protection Agency (EPA) defines sustainable material management (SMM) as an approach to serve human needs by using or reusing resources most productively and sustainably throughout their life cycles [14]. According to Umar in [15], the definition of sustainable building materials in construction is materials which domestically produced and sourced which decreases transportation cost and $\mathrm{CO}_{2}$ emission, consist of reused materials, have lower environmental impact, thermally effective, consume less energy than conventional materials, use of renewable resources, and economically sustainable. Umar also states that building materials life cycle organized into three phases, prebuilding, building, and post-building phase, which can be explained as follows:

1. Pre-building phase - the production and delivery processes of material up to the point of building assembly. This phase consists of finding raw material, manufacturing, packaging, and transportation to site.

2. Building phase - the building material useful life, begins at the point of installation, include the maintenance and repair, through all over the lifetime of material become a part of the building. Material choice will affect the overall health of building occupants.

3. Post-building phase - the building material at exhausted life, when their performance in a building has run out. In this phase, material can be entirely recycled, reused the component, or discarded.

\section{Research Methodology}

The method used for this study is a descriptive research that identifies and develop a framework for implementing green material management in construction industry that consists of concept, dimensions, elements, and indicators. Data collection method that was used is observation through literature study and also interview with experts from academic and ministry. The coverage topics of literature review that conducted is about supply chain management in construction industry, green supply chain management in construction industry, material management, construction material management, and sustainable material management in construction industry. The expert's opinion which come from The Minister of Public Work has an important role for determine the scale of certain indicators so that the metrics meet government standardization.

\subsection{Concept, Dimensions, and Elements of Green Material Management in Construction}

A research about green supply chain management in construction has been mentioned in sub section 2.2. The concept of green material management in construction becomes a part of green supply chain management framework of the construction industry that developed by Wibowo et al [12]. At the research, green material 
management is defined by a method to eliminate hazardous material or activities then replace with less harmful ones. From Delphi study, the research concludes there are seven components that becomes translation of green material management. They are material planning, procurement/purchasing, material storage, material handling, green material selection, green material sourcing, and also government regulation and legislation. The research also states that there are 16 elements which identified as translation of seven components that mentioned before.

Based on literature review and expert opinion, this study will develop the concept, dimensions, elements, and indicators of green material management in construction industry. The dimensions that identified are material planning, packaging, green transportation, material storage, and material handling that can be seen at Table 1 .

Table 1. Green material management dimensions.

\begin{tabular}{|c|c|c|}
\hline Dimension & Definition & References \\
\hline $\begin{array}{l}\text { Material } \\
\text { planning }\end{array}$ & $\begin{array}{l}\text { Process for selecting } \\
\text { material, planning the } \\
\text { requirement (include } \\
\text { quantity, time \& quality), } \\
\text { and selecting the supplier } \\
\text { with economic \& } \\
\text { ecological consideration }\end{array}$ & $\begin{array}{c}{[12,13,16,} \\
17]\end{array}$ \\
\hline Packaging & $\begin{array}{l}\text { Good packaging that } \\
\text { contributes to decrease } \\
\text { environment impact of a } \\
\text { product and lower } \\
\text { production cost, as well } \\
\text { as protect materials } \\
\text { during delivery }\end{array}$ & {$[15,18]$} \\
\hline $\begin{array}{c}\text { Green } \\
\text { transportation }\end{array}$ & $\begin{array}{l}\text { Practices to minimize the } \\
\text { environment effect and } \\
\text { breakage materials due to } \\
\text { transportation activity }\end{array}$ & $\begin{array}{l}{[11,1619,} \\
20,21,22]\end{array}$ \\
\hline Material storage & $\begin{array}{l}\text { Storage technique to } \\
\text { avoid waste, loss, and } \\
\text { any damage of materials }\end{array}$ & {$[12,13,23]$} \\
\hline $\begin{array}{l}\text { Material } \\
\text { handing }\end{array}$ & $\begin{array}{l}\text { Using the correct } \\
\text { technique in providing } \\
\text { the correct number of the } \\
\text { right material, in the right } \\
\text { time, place, and } \\
\text { circumstance }\end{array}$ & $\begin{array}{c}{[12,13,24,} \\
25]\end{array}$ \\
\hline
\end{tabular}

This five dimensions separate in two areas of construction projects member as illustrated in Figure 1 below.

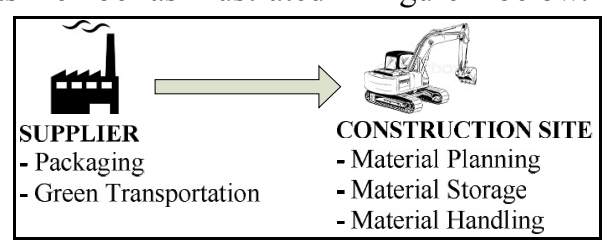

Fig. 1. Position of dimensions.

The next step is generating the elements from existing dimensions. Based on literature review, there are 16 elements. The elements define at Table 2.

Table 2. Green material management elements.

\begin{tabular}{|c|c|c|}
\hline \multicolumn{3}{|c|}{ Material Planning } \\
\hline Elements & Definition & References \\
\hline $\begin{array}{c}\text { Using material } \\
\text { that }\end{array}$ & $\begin{array}{c}\text { Choose material with the } \\
\text { lowest negative impact to }\end{array}$ & {$[12,16]$} \\
\hline
\end{tabular}

\begin{tabular}{|c|c|c|}
\hline $\begin{array}{l}\text { environmental } \\
\text { friendly }\end{array}$ & $\begin{array}{l}\text { environment that fulfils } \\
\text { ecological requirement } \\
\text { such as recyclability, } \\
\text { contamination, insulation } \\
\& \text { thermal conductivity, } \\
\text { and deconstruct ability }\end{array}$ & \\
\hline $\begin{array}{l}\text { Contract with } \\
\text { supplier }\end{array}$ & $\begin{array}{c}\text { There are strong } \\
\text { partnership culture that } \\
\text { actualized by contract } \\
\text { with suppliers, so the } \\
\text { level of material } \\
\text { availability can be } \\
\text { maintained }\end{array}$ & {$[12,17]$} \\
\hline $\begin{array}{l}\text { Select supplier } \\
\text { with ISO } 14001 \\
\text { certificate }\end{array}$ & $\begin{array}{l}\text { Choose supplier with ISO } \\
14001 \text { certificate to make } \\
\text { sure that the product and } \\
\text { internal business process } \\
\text { is environmental friendly }\end{array}$ & {$[12,17]$} \\
\hline $\begin{array}{l}\text { Quality control } \\
\text { of material }\end{array}$ & $\begin{array}{l}\text { Make sure that material } \\
\text { received on time in the } \\
\text { right quantity and meet } \\
\text { the specification }\end{array}$ & {$[12,13]$} \\
\hline \multicolumn{3}{|c|}{ Packaging } \\
\hline Elements & Definition & References \\
\hline $\begin{array}{l}\text { Selection of } \\
\text { packaging } \\
\text { material }\end{array}$ & $\begin{array}{l}\text { Better selection of } \\
\text { packaging material by } \\
\text { selecting the use of local } \\
\text { raw materials, weight } \\
\text { reduction, and the use of } \\
\text { recyclable materials }\end{array}$ & [18] \\
\hline $\begin{array}{c}\text { Design/concept } \\
\text { of package }\end{array}$ & $\begin{array}{l}\text { Design of package that } \\
\text { reduce resource and } \\
\text { energy consumption, and } \\
\text { also environmental } \\
\text { impact }\end{array}$ & [18] \\
\hline \multicolumn{3}{|c|}{ Green Transportation } \\
\hline Elements & Definition & References \\
\hline $\begin{array}{l}\text { Emission } \\
\text { reduction }\end{array}$ & $\begin{array}{l}\text { Reduce the carbon } \\
\text { emission that caused by } \\
\text { transportation activity, } \\
\text { including material, } \\
\text { employees, and other part } \\
\text { of construction project }\end{array}$ & {$[11,12]$} \\
\hline $\begin{array}{l}\text { Damage during } \\
\text { transportation }\end{array}$ & $\begin{array}{c}\text { Inherent risk during } \\
\text { transportation activity } \\
\text { that may cause breakage } \\
\text { in material }\end{array}$ & {$[12,19,20]$} \\
\hline $\begin{array}{l}\text { Difficulties for } \\
\text { delivery } \\
\text { vehicles } \\
\text { accessing } \\
\text { construction site } \\
\end{array}$ & $\begin{array}{c}\text { Delivery vehicles have } \\
\text { difficulty to accessing } \\
\text { construction site because } \\
\text { of large size or bad } \\
\text { layout management }\end{array}$ & {$[12,20,21]$} \\
\hline $\begin{array}{l}\text { Insufficient } \\
\text { protection } \\
\text { during } \\
\text { unloading } \\
\end{array}$ & $\begin{array}{c}\text { Insufficient protection for } \\
\text { material during unloading } \\
\text { may cause breakage }\end{array}$ & {$[12,20]$} \\
\hline $\begin{array}{l}\text { Inefficient } \\
\text { methods of } \\
\text { unloading }\end{array}$ & $\begin{array}{l}\text { Unloading methods have } \\
\text { to adjust by materials } \\
\text { (type, size, volume), } \\
\text { storage facility (including } \\
\text { the wide of path or aisle } \\
\text { to reach storage point), } \\
\text { cost, and flexibility }\end{array}$ & {$[12,20,22]$} \\
\hline \multicolumn{3}{|c|}{ Material Storage } \\
\hline Elements & Definition & References \\
\hline $\begin{array}{l}\text { Inappropriate } \\
\text { site storage } \\
\text { space leading to } \\
\text { damage or } \\
\text { deterioration }\end{array}$ & $\begin{array}{c}\text { Improper storage } \\
\text { facilities in construction } \\
\text { site (too small \& bad } \\
\text { layout) is one of reason } \\
\text { that may cause breakage } \\
\text { materials }\end{array}$ & {$[12,13]$} \\
\hline
\end{tabular}




\begin{tabular}{|c|c|c|}
\hline $\begin{array}{c}\text { Improper } \\
\text { storing methods }\end{array}$ & $\begin{array}{c}\text { Storing methods must to } \\
\text { adjust the characteristic } \\
\text { of materials (type, size \& } \\
\text { volume) }\end{array}$ & [12,23] \\
\hline \multicolumn{3}{|c|}{ Material Handling } \\
\hline Elements & Definition & References \\
\hline $\begin{array}{c}\text { On-site } \\
\text { transportation } \\
\text { methods from } \\
\text { storage to the } \\
\text { point of } \\
\text { application }\end{array}$ & $\begin{array}{c}\text { Handling methods for } \\
\text { moving materials, } \\
\text { including equipment } \\
\text { selection, size, location, } \\
\text { and time allocation }\end{array}$ & {$[12,24]$} \\
\hline $\begin{array}{c}\text { Inadequate } \\
\text { material } \\
\text { handling }\end{array}$ & $\begin{array}{c}\text { Material handling } \\
\text { without proper equipment } \\
\text { is one of reason that } \\
\text { cause accident and } \\
\text { breakage materials }\end{array}$ & {$[12,25]$} \\
\hline $\begin{array}{c}\text { Effective } \\
\text { material } \\
\text { handling }\end{array}$ & $\begin{array}{c}\text { Effective material } \\
\text { handling is not just about } \\
\text { equipment selection, but } \\
\text { also good plan of routing } \\
\text { materials }\end{array}$ & \\
\hline
\end{tabular}

After define the elements, the next step is generated the indicators. Indicators are completed with general scale to give better understanding and ease the application of framework for measurement purpose. There are 20 indicators as shown in Table 3.

Table 3. Green material management indicators

\begin{tabular}{|c|c|c|}
\hline \multicolumn{3}{|c|}{ Material Planning } \\
\hline Elements & Indicators & Scale \\
\hline \multirow{2}{*}{$\begin{array}{c}\text { Using material } \\
\text { that } \\
\text { environmental } \\
\text { friendly }\end{array}$} & $\begin{array}{l}\text { Percentage utilization of } \\
\text { recyclable construction } \\
\text { material }\end{array}$ & $0-100$ \\
\hline & $\begin{array}{l}\text { Percentage utilization of } \\
\text { hazardous material (such } \\
\text { as asbestos, PCB, PCT, } \\
\text { PAH, PCP) }\end{array}$ & $0-100$ \\
\hline $\begin{array}{l}\text { Contract with } \\
\text { supplier }\end{array}$ & $\begin{array}{l}\text { Percentage of contract } \\
\text { with suppliers }\end{array}$ & $0-100$ \\
\hline $\begin{array}{c}\text { Select supplier } \\
\text { with ISO } 14001 \\
\text { certificate } \\
\end{array}$ & $\begin{array}{l}\text { Percentage of suppliers } \\
\text { with ISO } 14001 \\
\text { certificate }\end{array}$ & $0-100$ \\
\hline $\begin{array}{l}\text { Quality control } \\
\text { of material }\end{array}$ & $\begin{array}{l}\text { Percentage of good } \\
\text { quality material that } \\
\text { received in site }\end{array}$ & $0-100$ \\
\hline \multicolumn{3}{|c|}{ Packaging } \\
\hline Elements & Indicators & Scale \\
\hline \multirow{2}{*}{$\begin{array}{l}\text { Selection of } \\
\text { packaging } \\
\text { material }\end{array}$} & $\begin{array}{l}\text { Use recyclable material } \\
\text { for packaging }\end{array}$ & $\begin{array}{c}1=\text { yes; } 0= \\
\text { no }\end{array}$ \\
\hline & $\begin{array}{l}\text { Use local resource for } \\
\text { produce package }\end{array}$ & $\begin{array}{c}1=\text { yes; } 0= \\
\text { no }\end{array}$ \\
\hline \multirow{2}{*}{$\begin{array}{c}\text { Design/concept } \\
\text { of package }\end{array}$} & $\begin{array}{c}\text { Optimization of } \\
\text { packaging volume }\end{array}$ & $\begin{array}{c}1=\text { yes; } 0= \\
\text { no }\end{array}$ \\
\hline & $\begin{array}{l}\text { Shared use of packaging } \\
\text { (standard packaging) }\end{array}$ & $\begin{array}{c}1=\text { yes; } 0= \\
\text { no }\end{array}$ \\
\hline \multicolumn{3}{|c|}{ Green Transportation } \\
\hline Elements & Indicators & Scale \\
\hline \multirow{2}{*}{$\begin{array}{l}\text { Emission } \\
\text { reduction }\end{array}$} & $\begin{array}{l}\text { Percentage of local } \\
\text { suppliers }\end{array}$ & $0-100$ \\
\hline & $\begin{array}{l}\text { Percentage of vehicle that } \\
\text { passes technical } \\
\text { specification test }\end{array}$ & $0-100$ \\
\hline $\begin{array}{c}\text { Damage during } \\
\text { transportation }\end{array}$ & $\begin{array}{c}\text { Percentage of broken and } \\
\text { lost material during } \\
\text { delivery }\end{array}$ & $0-100$ \\
\hline
\end{tabular}

\begin{tabular}{|c|c|c|}
\hline $\begin{array}{l}\text { Difficulties for } \\
\text { delivery } \\
\text { vehicles } \\
\text { accessing } \\
\text { construction site }\end{array}$ & $\begin{array}{l}\text { Percentage of tardiness in } \\
\text { material delivery }\end{array}$ & $0-100$ \\
\hline $\begin{array}{l}\text { Insufficient } \\
\text { protection } \\
\text { during } \\
\text { unloading }\end{array}$ & $\begin{array}{l}\text { Percentage of broken } \\
\text { material during unloading } \\
\text { process }\end{array}$ & $0-100$ \\
\hline $\begin{array}{l}\text { Inefficient } \\
\text { methods of } \\
\text { unloading }\end{array}$ & $\begin{array}{l}\text { Proper selection of } \\
\text { equipment for unloading } \\
\text { task }\end{array}$ & $\begin{array}{c}1=\text { yes; } 0= \\
\text { no }\end{array}$ \\
\hline \multicolumn{3}{|c|}{ Material Storage } \\
\hline Elements & Indicators & Scale \\
\hline $\begin{array}{c}\text { Inappropriate } \\
\text { site storage } \\
\text { space leading to } \\
\text { damage or } \\
\text { deterioration } \\
\end{array}$ & $\begin{array}{l}\text { Planning of the storage } \\
\text { place with some } \\
\text { consideration (such as } \\
\text { timing of initial buy \& } \\
\text { historical information) }\end{array}$ & $\begin{array}{c}1=\text { yes; } 0= \\
\text { no }\end{array}$ \\
\hline $\begin{array}{c}\text { Improper } \\
\text { storing methods }\end{array}$ & $\begin{array}{c}\text { There is SOP for material } \\
\text { storage process }\end{array}$ & $\begin{array}{c}1=\text { yes; } 0= \\
\text { no }\end{array}$ \\
\hline \multicolumn{3}{|c|}{ Material Handling } \\
\hline Elements & Indicators & Scale \\
\hline $\begin{array}{c}\text { On-site } \\
\text { transportation } \\
\text { methods from } \\
\text { storage to the } \\
\text { point of } \\
\text { application } \\
\end{array}$ & $\begin{array}{l}\text { There is SOP for } \\
\text { transporting material on } \\
\text { site }\end{array}$ & $\begin{array}{c}1=\text { yes; } 0= \\
\text { no }\end{array}$ \\
\hline $\begin{array}{l}\text { Inadequate } \\
\text { material } \\
\text { handling }\end{array}$ & $\begin{array}{c}\text { Use appropriate } \\
\text { equipment for material } \\
\text { handling }\end{array}$ & $\begin{array}{c}1=\text { yes; } 0= \\
\text { no }\end{array}$ \\
\hline $\begin{array}{l}\text { Effective } \\
\text { material } \\
\text { handling }\end{array}$ & $\begin{array}{l}\text { Planning of access \& } \\
\text { routing of material within } \\
\text { the construction site }\end{array}$ & $\begin{array}{c}1=\text { yes; } 0= \\
\text { no }\end{array}$ \\
\hline
\end{tabular}

\section{Discussion}

The green material management concept is applied to manufacture industry as a part of green supply chain management for the purpose of environmental sustainability [8]. This concept is focused on materials that become one of key element in manufacture. As known that materials count for considerable amount of construction cost as well as the largest contributor of waste generation, so this study aim to applied green material management in construction industry. Based on previous study, there is a framework of implementation green supply chain management in the construction industry which green material management becomes one of the concept [12]. The framework becomes a reference model for this study.

Previous study on sustainable building material in project life cycle and based on expert opinion, there are some modification in dimensions and elements of the model developed. This framework consists of five dimensions, 16 elements, and 20 indicators. Two dimensions (packaging and green transportation) become part of supplier area, and the others (material planning, material storage, and material handling) become part of construction site area.

The first dimension, material planning, has four elements to cover the green mission of the dimension that are to ensure that material is environmentally friendly, available on time at the best price, manufactured by 
environmental consideration, and meet the specification. The second dimension, packaging, has two elements to ensure that supplier considers environment aspect in selection material and design the package. The third dimension, green transportation, has five elements that coverage transportation processes from suppliers until material received in construction site storage area (include unloading processes). All processes should consider about emission, time accuracy, quality assurance of material. The fourth dimension, material storage, consists of two elements that examine planning of storage place and SOP for storage process. As known that large storage capacity is rarely available on site [12], this element must get close attention to avoid material waste caused by improper storage and protection facilities. The last dimension, material handling, has three elements to ensure that handling process held in right technique, appropriate equipment, and effective. These elements not only consider about availability material in right number, time, place, and condition, but also ensure the health and safety of construction workers from accident caused by inadequate material handling [25].

The important part of indicators is scaling process. Scale will make indicators become ease to understand and measured. In measurement application, scale is absolutely needed. In this study, scale is sourced by standard or regulation in construction industry. But the incompleteness of standard becomes limitation on identifying the detail scale.

In further application, this framework can be applied to pareto materials that have significant impact to overall project performance. This is for efficiency reason because the variety of materials that involved in a construction project.

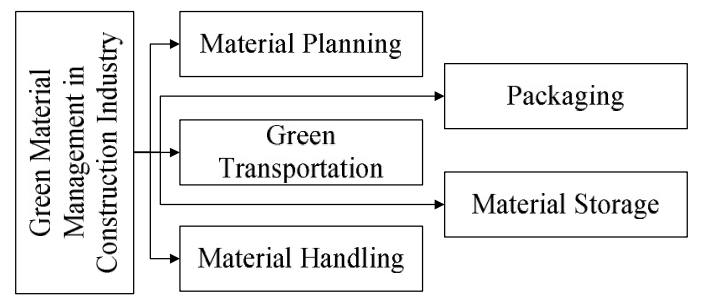

Fig. 2. Framework of green material management in the construction industry

\section{Conclusion}

Based on literature review and expert opinion, this study has proposed a framework for the implementation of green material management in the construction industry. This framework was adapted from green material management in manufacture with adjustment for construction characteristics, for example consideration of determining storage place and location in construction site, and also planning of access and routing material within the construction site to achieve effective material handling. The framework consists of five dimensions, 16 elements, and 20 indicators. The dimensions are material planning, packaging, green transportation, material storage, and material handling. This framework can be applied to measure implementation of green material management in the construction industry, but it still needs to validate by conduct empirical studies. Furthermore, the detail scale must be define to ease measurement process. In further research, a study about development measurement tools completed with detail scale and empirical studies in construction projects will be conducted to validate the assessment instrument. This research also has contribution to develop low carbon society. The application of green material management, especially green transportation give direct impact to reduce carbon emission by construction project.

\section{References}

1. S. Alwi, K. Hampson, S. Mohamed, IGLC-10 (2002)

2. G. Polat, G. Ballard, IGLC-12 (2004)

3. A. Garba, Y. O. Olaleye, N. S. Jibrin, J. Eng. Archt. 4, 1, 33-47 (2016)

4. L. Motete, J. Mbachu, R. Nkado, CIDB-1 (2003)

5. G. Ofori, Eur. J. Purch. Supp. Man. 6, 195-206 (2000)

6. M. Ghobakhloo, S. H. Tang, N. Zulkifli, M. Ariffin, Int. J. Innov. Man. Tech. 4, 1 (2013)

7. A. Cox, P. Ireland, M. Townsend, Man. Const. SC. Markets (2006)

8. L. L. Butkovic, A. G. Kauric, OFEL-4 (2016)

9. L. K. Toke, R. C. Gupta, M. Dandekar, ICIEOM (2010)

10. M. M. G. Elbarkouky, G. Abdelazeem, WIT Trns. Eco. Env. 179 (2013)

11. S. Balasubramanian, V. Shukla, SC Manag : Int. J, $22(2017)$

12. M. A. Wibowo, N. U. Handayani, A. Mustikasari, J. Ind. Eng. Managmt (2018)

13. N. Kasim, Int. Symp. Dev. Econ (2009)

14. IEI, A Sys. Apprch. Sust. Mat. Mangm. (2015)

15. U. A. Umar, M. F. Khamidi, MiCRA (2012)

16. N. Sunke, F. Schultman, CIB W115 Const. Mat. Stew (2009)

17. I. Adetunji, A. D. F. Prince, P. Fleming, Eng. Sust. 161 (2008)

18. S. G. Garcia, E. S. Mengual, P. L. Masana, G. Feijoo, X. Gabarrell, J. Rieradeval, M. T. Moreira, Env. Footp. Packg VII, 192-196 (2016)

19. J. Swinburne, C. E. Udeaja, N. Tait, Built Nat. Resrc. Papr. 3, 1 (2010)

20. T. Letcher, D. Vallero, Wast: A Hndbk. Mangm, 207-217 (2011)

21. A. Ahmadian, A. Akbarnezhad, T. H. Rashidi, S. T. Waller, ISARC31 (2014)

22. The INGAA Found Inc. Const. Saft. Consns. Guidln. (2017)

23. K. V. Patel, C. M. Vyas, Nat. Conf. Recn. Trn. Eng. Tech. (2011)

24. D. A. Wijesundera, F. C. Harris, Constr. Mang. Econm. (2006)

25. R. Azevedo, C. Martins, J. T. Teixeira, M. Barroso, Safty. Scie. 62 205-213 (2014) 